PRZEMYSLAW PIOTR DAMSKI

Akademia Finansów i Biznesu Vistula

\title{
Izolacjonizm i nieinterwencja w tradycji amerykańskiej polityki zagranicznej
}

\author{
Isolationism and non-interventionism \\ in the tradition of American foreign policy
}

\begin{abstract}
Commentators of the American foreign policy often criticize president Donald Trump's activity. They say of return of isolationism and abandoning by the United States its active role in Europe. However, American activity in this part of the world is rather new phenomenon. For most of its history the United States avoided interfering in European affairs. The founding myth of the USA was based on anti-European feelings. Europe was recognized as the main danger for American independence. For that reason, George Washington and the following presidents avoided, with increasing radicalism, political contacts with Europe (non-intervention). President Trump continues the policy of non-intervention in Europe, but unlike his predecessor he adopted more aggressive narration which takes much from anti-European ideas deeply rooted in the tradition of American foreign policy.
\end{abstract}

Keywords: US foreign policy, Monroe Doctrine, isolationism, Thomas Woodrow Wilson, Donald Trump

Słowa kluczowe: polityka zagraniczna USA, Doktryna Monroe'a, izolacjonizm, Thomas Woodrow Wilson, Donald Trump

\section{Polityka europejska prezydenta Donalda Trumpa (2017-2018)}

Każdy kolejny rok prezydentury Donalda Trumpa przynosi zaskoczenia. Krytycy konstatują, że prezydent USA lekceważy powszechnie przyjęte reguły, nie respektuje międzynarodowych zobowiązań i przejawia nonszalancki stosunek do protokołu dyplomatycznego ${ }^{1}$. Będące zapowiedzią tej polityki

1 A. Żelazińska, $W$ świecie dyplomacji coraz gorzej z kindersztuba, „Polityka” [online], 18.07.2017 [dostęp: 15.08.2017], dostępny w internecie: <http://www.polityka.pl/tygodnikpolityka/ludzieistyle/1712540,1,w-swiecie-dyplomacji-coraz-gorzej-z-kindersztuba.read>. 
hasło „Make America great again” przewijało się przez całą jego kampanię wyborczą. Po zaprzysiężeniu Donald Trump utrzymuje tę retorykę: poparł brexit $^{2}$, podpisaną z Australią umowę w sprawie imigracji publicznie nazwał głupią ${ }^{3}$, kilkakrotnie deklarował wprowadzenie wysokich ceł importowych ${ }^{4}$, w świetle czego na forum w Davos to Chiny stały się obrońcą wolnego handlu ${ }^{5}$. Wspieranie brexitu oraz niejasne związki prezydenta USA z Rosją ${ }^{6}$ zaowocowały oskarżeniami o działanie na szkodę Unii Europejskiej ${ }^{7}$, zwłaszcza po złym wrażeniu, jakie wywarł on w maju 2017 r. podczas pierwszej wizyty w Europie ${ }^{8}$. Nie mniej kontrowersji wywołała późniejsza podróż

2 K. Calamur, Why Europe is worried about Donald Trump's latest remarks, „The Atlantic” [online], 16.01.2017 [dostęp: 1.02.2017], dostępny w internecie: $<$ https://www.theatlantic.com/news/archive/2017/01/europe-trump/513248/>; K. Deikmann, M. Gove, Full transcript of interview with Donald Trump, „The Times” [online], 16.01.2017 [dostęp: 1.02.2017], dostępny w internecie: <http://www.thetimes.co.uk/article/full-transcript-of-interview-with-donald-trump-5d39sr09d $>$.

3 C. Phipps, Trump rages at ,, dumb deal" with Australia over refugee resettlement - as it happened, „The Guardian” [online], 2.02.2017 [dostęp: 14.08.2017], dostępny w internecie: $<$ http://www.theguardian.com/australia-news/live/2017/feb/02/donald-trump-dumb-deal-australia-refugee-resettlement-live $>$.

4 J. King, J. Diamond, Trump team floats a 10\% tariff on imports, „CNN” [online], 21.12.2016 [dostęp: 6.02.2017], dostępny w internecie: <http://www.cnn.com/2016/12/21/ politics/donald-trump-tariffs/index.html >; D. Lawler, Donald Trump's proposed tariff on US goods made overseas could extend to all imports, ally says, „The Telegraph” [online], 2.12.2016 [dostęp: 6.02.2017], dostępny w internecie: <http://www.telegraph. co.uk/news/2016/12/04/donald-trumps-proposed-tariff-us-goods-made-overseas-could-extend/>; A. Lowrey, The limits of „,Made in America” economics, „The Atlantic” [online], 20.07.2017 [dostęp: 14.08.2017], dostępny w internecie: <https://www.theatlantic. com/business/archive/2017/07/made-in-america/534339/>.

5 K. Hope, Davos 2017: Trump, China and Brexit set to dominate, „BBC News” [online], 16.01.2017 [dostęp: 21.06.2018], dostępny w internecie: $<$ http://www.bbc.com/news/business-38585505>; An odd moment for Davos, „The New York Times” [online], 18.01.2017 [dostęp: 1.02.2017], dostępny w internecie: <https://www.nytimes.com/2017/01/18/opinion/an-odd-moment-for-davos.html>.

6 K.K.R. Lai, A. Parlapiano, What we know about Donald Trump Jr's Russia meeting, „The New York Times” [online], 18.07.2017 [dostęp: 14.08.2017], dostępny w internecie: $<$ https://www.nytimes.com/interactive/2017/07/18/us/politics/donald-trump-jr-russia-meeting.html>; Russia. The „cloud” over the Trump White House, „BBC News” [online], 10.07.2017 [dostęp: 14.08.2017], dostępny w internecie: <http://www.bbc.com/ news/world-us-canada-38966846>.

7 Trump threatens Europe, says Brussels chief, „The Times” [online], 2.01.2017 [dostęp: 1.02.2017], dostępny w internecie: <http://www.thetimes.co.uk/article/trump-threatens-europe-says-brussels-chief-2lwx02k8d>.

8 D. Frum, Trump's trip was a catastrophe for U.S.-Europe Relations, „The Atlantic” [online], 28.05.2017 [dostęp: 14.08.2017], dostępny w internecie: $<$ https://www.theatlantic.com/ international/archive/2017/05/trump-nato-germany/528429/>; J. Henley, Donald Trump's Europe tour leaves leaders strangely shaken, „The Guardian” [online], 27.05.2017 [dostęp: 
do Polski. Według „The Economist” prezydenckie przemówienie brzmiało jak „,napisane przez polskich populistów”. Inne tytuły podkreślały, że nie odnosił się do jedności NATO i akcentował wspólne dla Europy i Rosji rzekome niebezpieczeństwo islamskie ${ }^{9}$. Napięcia amerykańsko-europejskie nasiliły się w wyniku jednostronnej deklaracji Trumpa o zerwaniu układu nuklearnego z Iranem, którego stronami były m.in. Francja, Wielka Brytania i Niemcy oraz Unia Europejska jako całość ${ }^{10}$. Prezydent USA nie poprzestał na tym i oświadczył m.in. zamiar nałożenia ceł na stal importowaną z Kanady, Meksyku (oba państwa to członkowie NAFTA) ${ }^{11}$ oraz UE, uzasadniając te

14.08.2017], dostępny w internecie: <http://www.theguardian.com/us-news/2017/may/27/ donald-trumps-europe-tour-leaves-leaders-shaken>.

9 Donald Trump's speech could have been written by Poland's populists, „The Economist" [online], 7.07.2017 [dostęp: 14.08.2017], dostępny w internecie: <https://www. economist.com/news/europe/21724892-warsaw-americas-president-barely-mentions-d emocracy-donald-trumps-speech-could-have-been>; J. Grierson, C. Davies, P. Wintour, Trump says west is at risk, during nationalistic speech in Poland, „The Guardian” [online], 6.07.2017 [dostęp: 14.08.2017], dostępny w internecie: <http://www.theguardian. com/us-news/2017/jul/06/donald-trump-warn-future-west-in-doubt-warsaw-speech>; G. Thrush, J.H. Davis, Trump, in Poland, asks if west has the 'will to survive', „The New York Times" [online], 6.07.2017 [dostęp: 14.08.2017], dostępny w internecie: <https:// www.nytimes.com/2017/07/06/world/europe/donald-trump-poland-speech.html>.

10 Zanim do tego doszło, nowy sekretarz stanu Michael „Mike” Pompeo zabiegał o poparcie Europy dla twardego stanowiska wobec Iranu, gwarantując w zamian bezpieczeństwo europejskich sojuszników. Ponieważ Iran wypełniał postanowienia umowy, UE nie widziała powodu, by przychylić się do stanowiska Waszyngtonu. W świetle późniejszych kroków Białego Domu wydaje się, że podróż Pompeo do Europy była jedynie zasłoną dymną, a jej fiasko miało usprawiedliwiać jednostronne działania Trumpa. EU's Donald Tusk takes aim at Donald Trump over Iran, trade tariffs, „Deutsche Welle” [online], 16.05.2018 [dostęp: 1.06.2018], dostępny w internecie: <http://www.dw.com/en/eus-donald-tusk-takes-aimat-donald-trump-over-iran-trade-tariffs/a-43813124>; G. Harris, Mike Pompeo, wasting no time, warns Europe about Iran deal, „The New York Times” [online], 28.04.2018 [dostęp: 1.06.2018], dostępny w internecie: <https://www.nytimes.com/2018/04/27/world/ europe/mike-pompeo-nato-russia-iran.html>; A. Zurcher, Three reasons behind Trump ditching Iran deal, „BBC News” [online], 8.05.2018 [dostęp: 1.06.2018], dostępny w internecie: $<$ https://www.bbc.com/news/world-us-canada-43902372>.

11 Prezydent Trump już wcześniej mówił o renegocjacji lub zniesieniu umowy NAFTA, a teraz stawia Meksykowi i Kanadzie ultimatum: „Fair deal or no deal”. P. Gillespie, Trump: Tearing up NAFTA ,will be fine”, „CNN Money” [online], 11.10.2017 [dostęp: 1.06.2018], dostępny w internecie: <http://money.cnn.com/2017/10/11/news/economy/ trump-nafta/index.html>; J. Sink, J. Wingrove, Trump warns Trudeau on Nafta: Fair deal or no deal, „Bloomberg” [online], 1.06.2018 [dostęp: 1.06.2018], dostępny w internecie: <https://www.bloomberg.com/news/articles/2018-06-01/trump-warns-trudeauon-nafta-fair-deal-or-no-deal-at-all>; D. Usborne, If Trump kills off Nafta it will be at his own peril - and the peril of America, „The Independent” [online], 20.10.2017 [dostęp: 1.06.2018], dostępny w internecie: $<$ http://www.independent.co.uk/voices/donald-trump-populist-kill-off-nafta-mexico-canada-end-of-globalisation-a8011976.html>. 
kroki jako konieczne do zapewnienia bezpieczeństwa narodowego Stanów Zjednoczonych ${ }^{12}$. Europa, skrytykowała działania administracji Trumpa i odczytała je jako sprzyjające Rosji. Jednocześnie skierowała sprawę amerykańskich ceł do dyskusji na forum Światowej Organizacji Handlu ${ }^{13}$.

Nie kwestionując słuszności przynajmniej części nieprzychylnych prezydentowi sądów, należy zwrócić uwagę, że wypowiedzi zarówno krytyków gospodarza Białego Domu, jak i jego samego cechuje ładunek emocjonalny, nawet jeśli te pierwsze są lepiej uargumentowane i mniej populistyczne ${ }^{14}$. Zapomina się, że zaangażowanie w sprawy międzynarodowe jest $\mathrm{w}$ amerykańskiej polityce zjawiskiem relatywnie nowym i wynika z odmiennych niż europejskie doświadczeń i realiów tego państwa. Gdy Trump wygrał wybory, popierający go historyk Nicholas Siekierski przewidywał, że nastąpi odejście od globalizmu i powrót do amerykanizmu ${ }^{15}$. Jan Woleński twierdził z kolei, że

12 A. Swanson, White House to impose metal tariffs on E.U., Canada and Mexico, „The New York Times" [online], 1.06.2018 [dostęp: 1.06.2018], dostępny w internecie: $<$ https://www.nytimes.com/2018/05/31/us/politics/trump-aluminum-steel-tariffs.html $>$.

13 J. Rankin, EU opens WTO case against Trump's steel and aluminium tariffs, „The Guardian" [online], 1.06.2018 [dostęp: 1.06.2018], dostępny w internecie: <https://www.theguardian.com/business/2018/jun/01/eu-starts-retaliation-against-donald-trumps-steel-and-aluminium-tariffs $>$.

14 Problem wpływu emocji na proces decyzyjny dostrzeżony został przez badaczy dość niedawno. Pomimo to ukazało się już stosunkowo wiele ciekawych publikacji na ten temat: Emotions in politics. The affect dimension in political tension, ed. N. Demertzis, Basingstoke 2013; J.M. Hughes, Emotion and high politics. Personal relations at the summit in late nineteenth-century Britain and Germany, Berkeley 1983; E. Hutchison, R. Bleiker, Theorizing emotions in world politics, „International Theory” 2014, vol. 6, No. 3, s. 491-514; A.A.G. Ross, Realism, emotion, and dynamic allegiances in global politics, „International Theory” 2013, vol. 5, no. 2, s. 273-299; B. Sasley, Emotions in international relations, „E-International Relations” [online], 12.06.2013 [dostęp: 5.03.2018], dostępny w internecie: <https://www.e-ir.info/2013/06/12/emotions-in-international-relations/>; tenże, Theorizing States' Emotions, „International Studies Review” 2011, vol. 13, No. 3, s. 452-476.

15 J. Żakowski, Trump nie najlepszy dla świata, ale najlepszy dla Ameryki?, „TOK FM” [online], 9.11.2016 [dostęp: 7.01.2017], dostępny w internecie: <http://audycje.tokfm. $\mathrm{pl} /$ podcast/Trump-nie-najlepszy-dla-swiata-ale-najlepszy-dla-Ameryki/43212>. Siekierski zdaje się rozumieć pod pojęciem amerykanizmu izolację. Idea amerykanizmu jako zespołu wartości politycznych zakorzeniona była w społeczeństwie USA niemal od początku jego istnienia. Pod koniec XIX w. Theodore Roosevelt definiował go jako odrzucenie kosmopolityzmu, ale w latach następnych jego pogląd ewoluował. Amerykanizm miał służyć „Bogu i rodzajowi ludzkiemu” i oznaczać internacjonalizm. L.E. Ambrosius, The Great War, Americanism revisited, and the anti-Wilson crusade, [w:] A companion to Theodore Roosevelt, ed. S. Ricard, Chichester, West Sussex-Malden, MA 2011, s. 476-477; A.M. Johnston, Sex and Gender in Roosevelt's America, [w:] A companion to Theodore Roosevelt..., s. 120. 
USA wracają do Doktryny Monroe'a ${ }^{16}$. Charakterystyczne dla obu tych opinii akcentowanie powrotu wskazuje na zakorzenioną w amerykańskiej polityce zagranicznej rezerwę do Europy. Działania prezydenta Trumpa nie są tu więc niczym wyjątkowym i choć zaskakują komentatorów, to mają umocowanie w tradycji i historycznej aktywności dyplomacji USA.

Celem niniejszego artykułu jest przeglądowe przedstawienie historii amerykańskiego izolacjonizmu i polityki nieinterwencji, a także wpływu dziedzictwa George'a Washingtona i Thomasa Jeffersona na kształtowanie się polityki zagranicznej USA i jej późniejszą ewolucję. Pozwoli to lepiej zrozumieć powrót Stanów Zjednoczonych do bardziej chłodnych stosunków ze Starym Kontynentem.

\section{Washington, Jefferson i fundamenty amerykańskiej izolacji}

Trudno znaleźć jedno pojęcie, które trafnie charakteryzowałoby całą politykę USA w XIX i XX w. Zazwyczaj określano ją jako izolacjonizm i nieinterwencję. W okresie globalnej hegemonii Waszyngtonu częściej mówiło się jednak o unilateralizmie, wskazując na element egoizmu w amerykańskiej polityce zagranicznej, który część badaczy myli ze swobodą działania USA $^{17}$. Wydaje się, że wszystkie te trzy terminy mają wspólne źródło, wynikające $\mathrm{z}$ odmiennego od europejskiego doświadczenia oraz położenia geopolitycznego USA.

Przed ogłoszeniem niepodległości trzynaście kolonii było częścią systemu eurocentrycznego ${ }^{18}$. Jako terytorium wchodzące w skład pierwszego imperium brytyjskiego ${ }^{19}$ ponosiły wszelkie tego konsekwencje, także militarne, co rzutowało na doświadczenia kolonistów, stopniowo postrzegających

16 J. Woleński, Donald Trump wraca do stynnej Doktryny Monroe'a. Polski nie powinno to cieszyć, „Polityka” [online], 23.01.2017 [dostęp: 1.02.2017], dostępny w internecie: $<$ http://www.polityka.pl/tygodnikpolityka/swiat/1691298,1, donald-trump-wraca-doslynnej-doktryny-monroea-polski-nie-powinno-to-cieszyc.read $>$.

17 Por. J.L. Gaddis, Surprise, security, and the American experience, Cambridge, MA 2004; Ł. Wordliczek, Czy nowy prezydent Stanów Zjednoczonych prowadzi nowa polityke zagraniczna i dlaczego nie?, [w:] Amerykomania. Księga jubileuszowa profesora dra hab. Andrzeja Mani, t. 1, red. W. Bernacki, A. Walaszek, Kraków 2009, s. 233-246.

18 G.C. Herring, From colony to superpower. U.S. foreign relations since 1776, New York 2008, s. 12-13.

19 Pierwsze imperium brytyjskie to określenie nieformalne, używane przez historyków do odróżnienia systemu rządów kolonialnych Albionu przed rewolucją amerykańską i po niej. 
wojnę jako odprysk waśni monarchów w Europie ${ }^{20}$. To co europejskie oddzielano tym samym od tego co amerykańskie, a charakter stosunków gospodarczych między imperiami a ich koloniami tylko to ułatwiał. Metropolia znajdowała się w rdzeniu ówczesnego systemu świata, podczas gdy podległe jej terytoria - zgodnie z założeniami merkantylizmu ${ }^{21}$ - były obszarami peryferyjnymi, zaopatrującymi centrum ${ }^{22}$.

Koloniści początkowo podejmowali próby zwiększenia samorządności w ramach systemu ${ }^{23}$, ale metropolia oponowała, uznając, że ograniczałoby to jej prerogatywy. Przyczyniła się tym samym do wykształcenia się wśród kolonistów wizerunku brytyjskiego/europejskiego despotyzmu. Choć sytuacja gospodarcza była dobra, to subiektywne odczucia kolonistów i nierównomierny podział zysków wynikających z rosnącej siły ekonomicznej kolonii doprowadziły wespół z czynnikami politycznymi do erupcji ${ }^{24}$. Deklaracja niepodległości ogłaszająca suwerenność dotychczasowych kolonii była także aktem izolacji, choć podkreślano w niej prawo nowo powstałego państwa do zawierania sojuszy i prowadzenia wojen ${ }^{25}$. Komunikowano się więc z Europą, używając pojęć powszechnie zrozumiałych dla tamtejszych państw i traktowanych przez nie jako atrybuty suwerenności.

W Stanach Zjednoczonych nie brakowało jednak przeciwników utrzymywania relacji politycznych z Europą i ograniczenia ich wyłącznie do handlu ${ }^{26}$. Na przykład John Adams jeszcze przed ogłoszeniem niepodległości obawiał się, że Stary Kontynent będzie chciał „wciągnąc nas w swoją prawdziwą lub wyimaginowaną równowagę sił. [...] Sądzę jednak, że naszą zasadą powinno być niemieszanie się" w sprawy europejskie ${ }^{27}$. Amerykańska dyplomacja

20 Dlatego zmagania w Ameryce będące częścią wojny o sukcesję austriacką funkcjonują w amerykańskiej historiografii jako wojna królowej Anny, a wojna o sukcesję hiszpańską - jako wojna króla Jerzego. G.B. Tindall, D.E. Shi, America. A narrative history, New York 2016, s. 130; M. A. Jones, Historia USA, Gdańsk 2003, s. 42.

21 Niektórzy badacze kwestionują sens użycia tego terminu, skłaniając się bardziej w kierunku colbertyzmu lub nacjonalizmu ekonomicznego. Zob. R.E. Cameron, L. Neal, Historia gospodarcza świata. Od paleolitu do czasów najnowszych, Warszawa 2010, rozdz. 6.

22 I. Wallerstein, The modern world-system. Capitalist agriculture and the origins of the European world-economy in the sixteenth century, New York-San Francisco-London 1974, s. 349.

23 J. Daszyńska, Misje Benjamina Franklina w Londynie w latach 1757-1775, Łódź 1994.

24 I. Wallerstein, The modern world-system III. The second era of great expansion of the capitalist world-economy, 1730-1840s, Berkeley-Los Angeles-London 2011, s. 195-198.

25 D. Perkins, The American approach to foreign policy, Cambridge, MA 1955, s. 10; The declaration of independence, 4.07.1776 [dostęp: 16.05.2018], dostępny w internecie: $<$ http://www.ushistory.org/declaration/document/>.

26 G.C. Herring, From colony..., s. 18-22; G. B. Tindall, D.E. Shi, America ..., s. 300-302.

27 J.B. Moore, The principles of American diplomacy, New York 1918, s. 198-199. 
miała być bardziej demokratyczna od europejskiej, dlatego też legislatywa nowo powstałej republiki od początku współdecydowała o jej polityce zagranicznej, co powodowało większą zależność między sprawami wewnętrznymi i zewnętrznymi. Stan ten utrzymał się pomimo przekazania polityki zagranicznej w kompetencje egzekutywy. Ze względu na niechęć do wszystkiego, co kojarzono z arystokracją, unikano nadawania przedstawicielom dyplomatycznym rangi ambasadora ${ }^{28}$.

Choć w Stanach Zjednoczonych niechętnie patrzono na relacje polityczne z Europą, to realia skłaniały do pragmatyzmu i korekty przyjętych założeń. W 1778 r. zawarto więc sojusz z Francją, mający wzmocnić młodą republikę w jej zmaganiach z Wielką Brytanią. Gdy jednak rewolucyjna już Francja stanęła $\mathrm{w}$ obliczu starcia $\mathrm{z}$ państwami ancien régime'u, Thomas Jefferson i Alexander Hamilton skłonili prezydenta George'a Washingtona do ogłoszenia neutralności ${ }^{29}$. W swym pożegnalnym orędziu z 1796 r. ponownie mówił on o trzymaniu się z dala od Europy, a wiązanie się z jej państwami nazywał sztucznym i nierozważnym. Ich politykę uważał za zależną od humorów i kaprysów, mogącą skutkować wpływem obcych na Amerykę. Zalecał zatem ograniczenie ,powiązań politycznych do niezbędnego minimum" i rozwijania stosunków handlowych. Fundamentem owej prawdziwej polityki amerykańskiej miało być „powstrzymanie się od stałych sojuszy z jakimkolwiek państwem"30.

28 Po utworzeniu Departamentu Stanu prezydent mianował odpowiedzialnych przed sobą szefów placówek dyplomatycznych, ale uczynił to ,za radą i zgodą Senatu”. G. Hunt, Department of State of the United States. Its history and functions, New Haven, CT-LondonOxford 1914, s. 2; E. Plischke, U.S. Department of State. A reference history, Westport, Conn 1999, s. 7-19. Wszyscy ówcześni wysłannicy to posłowie (ministrowie pełnomocni lub ministrowie rezydenci) albo chargé d'affaires, ewentualnie konsulowie. Służba dyplomatyczna pozostawała jednak niedofinansowana, co dawało senackiej Komisji Spraw Zagranicznych większy wpływ na obsadę placówek dyplomatycznych, pomimo że według Jeffersona senatorowie nie mogli odrzucić prezydenckich nominacji. Jeżeli chodzi o wynagrodzenia dyplomatów, stwierdzał, że są ,znacznie niższe niż pensje [urzędników - P.P.D.] tego samego stopnia na dworach europejskich i niższe, niż wymaga tego dobro publiczne". G. Hunt, Department of State..., s. 105-109; A. Mania, Department of State 1789-1939. Pierwsze 150 lat udziału w polityce zagranicznej USA, Kraków 2011, s. 84; E. Plischke: U.S. Department of State..., s. 49.

29 Choć Jefferson i Hamilton popierali neutralność, to różnili się w ocenie ważności traktatu sojuszniczego z 1778 r. Pierwszy uznawał go za wiążący, drugi - za nieważny, gdyż zawarty z rządem burbońskim, a nie republikańskim, który właśnie toczył wojnę. S. Bernstein, Jefferson and the French Revolution, „Science \& Society” 1943, vol. 7, No. 2, s. 136-137; J.L. Harper, American Machiavelli. Alexander Hamilton and the origins of U.S. foreign policy, Cambridge, UK-New York 2004, s. 103-114.

30 G. Washington, Farewell address, „The Avalon Project” [online], dostępny w internecie [dostęp: 8.04.2016]: <http://avalon.law.yale.edu/18th_century/washing.asp>. 
W tym kategorycznym stwierdzeniu krył się pragmatyzm okresu rewolucji amerykańskiej. Washington zaznaczał, że Europa to coś innego niż Ameryka i należy jej unikać, bo ingerencja w wewnętrzne sprawy Starego Kontynentu mogłaby skutkować zarażeniem europejskim despotyzmem i zbrukać święte wartości pokoju i demokracji, na których zbudowano amerykańską republikę. Konieczne było zatem odizolowanie się od tego świata i nieingerowanie w jego wewnętrzne sprawy. Washington postulował jednak unikanie tylko stałych sojuszy, dopuszczając doraźne. Biorąc pod uwagę, że alians z Francją zawarto w obliczu zagrożenia, można wnioskować, że pierwszemu prezydentowi USA chodziło o analogiczne sytuacje. Gdyby nieinterwencja stała się przeszkodą dla utrzymania izolacji, gdyby bezpieczeństwo Stanów Zjednoczonych stanęło pod znakiem zapytania, wówczas międzynarodowy mariaż byłby możliwy.

Jeden z kolejnych prezydentów, Thomas Jefferson, w swoim orędziu inauguracyjnym poszedł dalej. Podobnie jak Washington uważał, że europejski autokratyzm i amerykańska demokracja były nie do pogodzenia ${ }^{31}$ i jedynie polityczna i moralna separacja mogła zagwarantować ,zdrowie i długowieczność republiki”"32. W odróżnieniu od niego odrzucał jednak wszelkie wiążące alianse, podkreślając, że USA łączy z innymi państwami - przede wszystkim europejskimi - wyłącznie stosunek handlowy ${ }^{33}$.

Washington i Jefferson nie przywoływali relacji handlowych jedynie w opozycji do stosunków politycznych. Ograniczenia handlowe utożsamiane były z panowaniem brytyjskim, tymczasem pomimo uznania niepodległości swych dawnych kolonii Albion chętniej postrzegał Nowy Świat jako rynek niż równorzędnego partnera gospodarczego. W tym sensie zależność USA od Wielkiej Brytanii utrzymywała się $e^{34}$ i dopiero kontrowersyjna wojna ${ }^{35} \mathrm{z}$ lat $1812-1814$ stworzyła warunki do rzeczywistej suwerenności i separacji od Europy, pozwa-

31 Z. Libiszowska, Tomasz Jefferson, Wrocław 1984, s. 273.

32 R. Kagan, Dangerous nation, New York 2006, s. 107.

33 T. Jefferson, First inaugural address, 03 Apr. 1801, [w:] The papers of Thomas Jefferson, vol. 33, Princeton, NJ 2006, s. 148-152. Europa stanowiła w tym czasie punkt odniesienia dla kształtowania się amerykańskiej mentalności i kultury, także politycznej. Państwa europejskie kontrolowały jeszcze znaczną część Ameryki Łacińskiej, a stosunki USA z innymi rejonami świata były ograniczone. Stąd oczywiste wydaje się, że Jefferson w pierwszej kolejności myślał wówczas o Europie, a dopiero w drugiej o potencjalnych relacjach z państwami pozaeuropejskimi.

34 I. Wallerstein, The modern world-system III..., s. 251.

$35 \mathrm{R}$. Buel, America on the brink. How the political struggle over the war of 1812 almost destroyed the young republic, New York, NY 2005. Przez niektórych historyków i ówczesnych polityków amerykańskich bywa nieco na wyrost nazywana drugą wojną o niepodległość. H.W. Brands, Andrew Jackson. His life and times, New York 2006, rozdz. 13. 
lając jednocześnie na stopniową poprawę wzajemnych relacji, co wyraźnie odczuwalne stało się dopiero na przełomie XIX i XX w.

Oświadczenia wygłoszone w orędziach Washingtona i Jeffersona były jednostronne, ale nie była to praktyka obca innym państwom. Dla graczy europejskich miały one jedynie wartość informacyjną, dopóki nie nawoływały do ich atakowania. Poza oczywistą charakterystyką amerykańskiej polityki zagranicznej sformułowane w orędziach tezy były przede wszystkim odpowiedzią na zapotrzebowanie wewnętrzne ${ }^{36}$. Amerykanie bali się o świeżo zdobytą niepodległość, a podkreślanie separacji od Europy pomagało stabilizować nastroje społeczne. Prowadzenie takiej polityki możliwe było dzięki położeniu geograficznemu USA, które zapewniało darmowe bezpieczeństwo, „oparte na darze natury, którym były trzy przepastne akweny oddzielające to państwo od innych mocarstw mogących poważnie zagrozić jego bezpieczeństwu" ${ }^{37}$. Zalety odizolowania i dalekiego położenia doceniał już Washington ${ }^{38}$, a Jefferson dzięki zakupowi Luizjany pozbył się z Ameryki Północnej jednego z ważniejszych europejskich graczy ${ }^{39}$. Trzeba podkreślić, że sprzyjały mu wojny w Europie ${ }^{40}$ i koloniach hiszpańskich w Ameryce Łacińskiej, bo choć wierne nieinterwencji USA powstrzymały się od aktywnego udziału w tych wydarzeniach, to sytuacja rozwijała się dla nich korzystnie. W 1835 r. Alexis de Tocqueville mógł więc stwierdzić: „Niebezpieczeństwa zewnętrzne nie są tu [w Ameryce - P.P.D.] nigdy poważne"41 .

\section{Doktryna Monroe’a}

Na politykę zagraniczną Stanów Zjednoczonych wpływał też ład międzynarodowy ustanowiony w 1815 r. w Wiedniu. Stworzono wówczas quasi-policyjny system Świętego Przymierza, który od 1820 r. miał prawo do interwencji

36 „W im bardziej niepewnej i niebezpiecznej sytuacji znajduje się społeczeństwo - pisał przenikliwy obserwator Ameryki Alexis de Tocqueville - tym bardziej daje się odczuć potrzeba ciągłości w dziedzinie stosunków zagranicznych [...]”. A. de Tocqueville, $O$ demokracji w Ameryce, Warszawa 2005, s. 117-118.

37 C.V. Woodward, The age of reinterpretation, „The American Historical Review” 1960, vol. 66, No. 1, s. 2.

38 G. Washington, Farewell Aaddress...

39 B. J. Balleck, When the ends justify the means. Thomas Jefferson and the Louisiana Purchase, „Presidential Studies Quarterly” 1992, vol. 22, No. 4, s. 679-696. Francji pozostały w Zachodniej Hemisferze jedynie niewielkie posiadłości.

40 W.M. Sloane, The world aspects of the Louisiana Purchase, „The American Historical Review" 1904, vol. 9, No. 3, s. 507.

41 A. de Tocqueville, $O$ demokracji..., s. 118. 
przeciw rewolucjom, co teoretycznie pozwalało na działania w Nowym Świecie. Kanclerz Austrii Klemens von Metternich popierał restaurację imperium hiszpańskiego w Ameryce ${ }^{42}$, dlatego sekretarz stanu prezydenta Jamesa Monroe'a bał się, że Europa będzie chciała przywrócić tam także panowanie Brytyjczyków ${ }^{43}$.

Obawy rządu USA potęgowała deklaracja cara Aleksandra I o rosyjskim osadnictwie w Ameryce Północno-Zachodniej ${ }^{44}$. Nie żywił on wobec USA wrogich zamiarów ${ }^{45}$, ale ważniejsze od rzeczywistych intencji cesarza było to, jak jego posunięcia interpretowano nad Potomakiem ${ }^{46}$. Podobnie rzecz się miała z potencjalną interwencją Świętego Przymierza. Tego rodzaju akcja pozostawała poza jego możliwościami finansowymi i logistycznymi, zwłaszcza wobec sprzeciwu Wielkiej Brytanii ${ }^{47}$, która zdążyła wyprzeć z tej części świata Hiszpanów i Portugalczyków, uzależniając od siebie finansowo i militarnie ich niedawne posiadłości ${ }^{48}$. Istotne było jednak to, że rząd amerykański uznał taką możliwość za zagrożenie dla izolacji USA. Zaowocowało to słowami prezydenta Monroe'a wypowiedzianymi w orędziu z 1823 r., które często uważane są za fundament amerykańskiej polityki zagranicznej. Wychodząc od kwestii Rosji, przywołał on tradycje polityki Stanów Zjednoczonych nakreślone przez Washingtona i Jeffersona. Zwrócił uwagę na odmienność systemów amerykańskiego i europejskiego oraz désintéressement USA wobec spraw Starego Kontynentu. Nowością w jego przemówieniu był natomiast stosunek do Zachodniej Hemisfery. Dotychczasowi prezydenci uznawali korzyści

42 W.S. Robertson, Metternich's attitude toward revolutions in Latin America, ,The Hispanic American Historical Review" 1941, vol. 21, No. 4, s. 538.

43 M.T. Gilderhus, The Monroe doctrine. Meanings and implications, „Presidential Studies Quarterly" 2006, vol. 36, No. 1, s. 5-16.

44 Petersburg miał wówczas pod kontrolą Alaskę i prowadził działalność handlową w północnej Kalifornii, gdzie kontrolował Fort Ross. K. N. Owens, Frontiersman for the Tsar. Timofei Tarakanov and the expansion of Russian America, „Montana. The Magazine of Western History" 2006, vol. 56, s. 3-21.

45 I.C. Nichols, The Russian ukase and the Monroe Doctrine. A re-evaluation, „Pacific Historical Review" 1967, vol. 36, No. 1, s. 13-26.

46 D. Perkins, A history of the Monroe Doctrine, Boston 1955, s. 30-31.

47 Nie była członkiem Świętego Przymierza, ale brała udział w jego spotkaniach jako członek czwórprzymierza.

48 E.J. Hobsbawm, The age of revolution. Europe 1789-1848, London 1988, s. 51; T. Łepkowski, Ameryka Lacińska. Rewolucje niepodległościowe i poczatki nowych państwowości, [w:] Europa i świat w epoce restauracji, romantyzmu i rewolucji, 1815-1849, t. 2, red. W. Zajewski, Warszawa 1991, s. 190-191; H. Nicolson, The Congress of Vienna. A study in allied unity: 1812-1822, New York 1964, s. 69-73; D. Perkins, A history..., s. 50-55; J. Sexton, The Monroe Doctrine. Empire and nation in nineteenth-century America, New York 2011, s. 62-63. 
geopolitycznego położenia USA za bezsprzeczne; izolacja oraz nieinterwencja miały ich zdaniem wystarczyć do utrzymania bezpieczeństwa kraju. Monroe zanegował to rozumowanie i przesunął punkt ciężkości z państwa na kontynent ${ }^{49}$. Uważał, że przed przyszłą kolonizacją któregokolwiek z mocarstw należało zabezpieczyć całą Amerykę, a każda próba rozszerzenia europejskiego systemu do jakiejkolwiek części tej hemisfery powinna być traktowana jako zagrożenie dla pokoju i bezpieczeństwa Stanów Zjednoczonych. Uznał przy tym aktualny stan posiadania Europejczyków w Nowym Świecie, nieinterwencja miała bowiem obowiązywać na podobnych zasadach jak w przypadku Starego Kontynentu. Jeżeli jednak jakiś naród latynoamerykański ogłosiłby i utrzymał niepodległość, to wrogość wobec niego uznawana by była za równoznaczną z nieprzyjaznym stosunkiem wobec USA ${ }^{50}$. Monroe wysunął zatem na pierwszy plan izolację. Nieinterwencja w dalszym ciągu miała jej strzec, jednak obszar izolowany rozciągnięty został na niepodległe tereny obu Ameryk. Naruszenie tej strefy przez Europę mogło sprowokować porzucenie nieinterwencji.

W rzeczywistości deklaracja prezydenta zmieniła niewiele ${ }^{51}$. Latynoamerykańskie inicjatywy sojusznicze zostały zignorowane, a Zachodnia Hemisfera oddana pod dominację brytyjską ${ }^{52}$, co de facto było kontynuacją polityki Washingtona i Jeffersona ${ }^{53}$. Doktryna Monroe'a była zmianą, na którą Stany Zjednoczone nie były wówczas gotowe. Nawet warunkowe zarzucenie nieinterwencji oznaczałoby większą aktywność międzynarodową, co stało w sprzeczności z wcześniejszymi paradygmatami. „Polityka zagraniczna Amerykanów jest nader prosta - zauważał Tocqueville. - Można niemal powiedzieć, że nikt ich nie potrzebuje i oni nie potrzebują nikogo. Ich niezależność nie bywa zagrożona" 54 .

49 Piszący te słowa jest świadomy, że problem autorstwa doktryny oraz uczestnictwo Thomasa Jeffersona i Johna Quincy'ego Adamsa w jej opracowaniu czynią tę sprawę nieco bardziej skomplikowaną. E.P. Crapol, John Quincy Adams and the Monroe Doctrine. Some new evidence, „Pacific Historical Review” 1979, vol. 48, No. 3, s. 413-418; T.R. Schellenberg, Jeffersonian origins of the Monroe Doctrine, „The Hispanic American Historical Review" 1934, vol. 14, No. 1, s. 1.

50 J. Monroe, Monroe Doctrine, „The Avalon Project”, 2.12.1823 [dostęp: 26.09.2016], dostępny w internecie: <http://avalon.law.yale.edu/19th_century/monroe.asp $>$.

51 Kongres zareagował na nią chłodno, w państwach europejskich natomiast albo ją ignorowano, albo wyrażano oburzenie. L. Pastusiak, Droga Stanów Zjednoczonych do mocarstwowości. Studia amerykanistyczne, Łódź 2007, s. 90-94.

52 Więcej zob. R. Mroziewicz, Dyplomacja USA wobec Ameryki Centralnej 1822-1850, Wrocław 1986.

53 D. Perkins, The Monroe Doctrine 1823-1826, Cambridge, Mass 1932, s. 192-193.

54 A. de Tocqueville, $O$ demokracji..., s. 118. 


\section{Ewolucja idei nieinterwencji w obliczu wyzwań międzynarodowych}

Przez większą część XIX w. USA zapewniały sobie izolację poprzez powstrzymywanie się od wszelkich interwencji w sprawy zewnętrzne. Potęga gospodarcza republiki rosła, a państwo nie wykorzystywało swego międzynarodowego potencjału ${ }^{55}$ i nie dążyło do maksymalizacji siły ani w celach defensywnych, ani by uzyskać status hegemona ${ }^{56}$. Zasadniczo, pomimo niewielkich odstępstw, izolacja i nieinterwencja wciąż pozostawały dogmatami, co stopniowo stawało się kłopotliwe.

W XIX w. świat robił się bardziej europejski niż kiedykolwiek wcześniej. Standardy charakterystyczne dla Starego Kontynentu, włącznie z handlem i dyplomacją, stały się normami globalnymi ${ }^{57}$. W 1858 r. konserwatywny brytyjski polityk Benjamin Disraeli oskarżał USA o izolacjonizm, który utożsamiał z Doktryną Monroe'a i pozostawaniem Stanów Zjednoczonych poza europejskim systemem prawa międzynarodowego ${ }^{58}$. Amerykanie jednak wcale nie byli zainteresowani zmianą tego stanu rzeczy. Choć każdy większy dziennik w USA informował o sytuacji na świecie, Departament Stanu wciąż w niewielkim stopniu angażował się poza Zachodnią Hemisferą, narażając się tym samym na ataki amerykańskiej prasy ${ }^{59}$. Przeciętny Amerykanin nie miał jednak pojęcia o Doktrynie Monroe'a ${ }^{60}$. Siły narodu i państwa skon-

55 Fareed Zakaria określił to mianem „holenderskiej choroby [...] która przeszkodziła narodowi cieszącemu się nieporównywalną indywidualną koniunkturą i sprawnością handlową w stworzeniu państwa o wielkich wpływach i potędze”. F. Zakaria, From wealth to power. The unusual origins of America's world role, Princeton, NJ 1998, s. 5.

56 R. Rosencrance, Z. Steiner, History and neorealism reconsidered, [w:] History and neorealism, ed. E. R. May, R. Rosencrance, Z. Steiner, Cambridge-New York 2010, s. 341-365.

57 Świetnie ukazał to Jürgen Osterhammel. Zob. J. Osterhammel, Historia XIX wieku. Przeobrażenie świata, Poznań 2013.

58 B. Disraeli, Our relations with the United States, June 16, 1856, [w:] Hansard parliamentary debates. House of commons, vol. 142, London 1856, s. 1499-1513.

59 P. Kennedy, Mocarstwa świata. Narodziny, rozkwit, upadek. Przemiany gospodarcze $i$ konflikty zbrojne $w$ latach 1500-2000, Warszawa 1984, s. 246 . W sytuacji gdy mocarstwa europejskie dokonały już profesjonalizacji swej służby zagranicznej w oparciu o model dyplomatów zawodowych, w USA była ona narzędziem do wynagradzania zwolenników politycznych. Por.: P.G. Lauren, Diplomats and bureaucrats. The first institutional responses to twentieth-century diplomacy in France and Germany, Stanford, CA 1976; T.G. Otte, The foreign office mind. The making of British foreign policy, 1865-1914, Cambridge-New York 2011; R.D. Schulzinger, The making of the diplomatic mind. The training, outlook, and style of the United States Foreign Service officers, 1908-1931, Middletown, Connecticut 1975, s. 3-51; Z. Steiner, Foreign Office and foreign policy, 1898-1914, London 1969.

60 R.A. Humphreys, Presidential address. Anglo-American rivalries and the Venezuela Crisis of 1895, „Transactions of the Royal Historical Society Fifth Series” 1967, vol. 17, s. 146. 
centrowane były na ekspansji na zachód i wypełnianiu Boskiego Przeznaczenia (Manifest Destiny) ${ }^{61}$.

Obawa przed europejskimi zakusami w Zachodniej Hemisferze wciąż jednak istniała. W obliczu narastającego antagonizmu Północy i Południa sekretarz stanu William Seward zaczął myśleć o wojnie z Europą ${ }^{62}$. Uważał, że politykę nieinterwencji trzeba porzucić, ale nie w celu utrzymania izolacji, tylko zintegrowania narodu. Idealnym pretekstem był zamiar zainstalowania przez Europejczyków w Meksyku księcia Maksymiliana Habsburga, ale nie wykorzystano go na czas. Po wybuchu wojny secesyjnej było już za późno - Seward nie podejmował dalszych działań, ponieważ USA toczyły „walkę o własne życie”63. Dopiero gdy zwycięstwo Unii nad Konfederacją stało się pewne, zdecydował się na interwencję - ale już w obronie izolacji - i przekonał Napoleona III, że sytuacja w Meksyku zagrażała przyjaźni francusko-amerykańskiej ${ }^{64}$.

Sprawa meksykańska uświadomiła Amerykanom, że izolacja nie jest gwarantem bezpieczeństwa. Pojawiły się przy tym głosy, że USA i tak stały się już częścią systemu równowagi sił ${ }^{65}$. Bezpieczeństwo Stanów Zjednoczonych miało więc odtąd $\mathrm{w}$ dużo mniejszym stopniu niż dotychczas polegać na polityce nieinterwencji. Dopuszczano zatem sytuację, którą w 1823 r. przewidywał Monroe, dlatego właśnie w 1868 r. Seward mówił w kontekście Meksyku o zwycięstwie doktryny, choć wcześniej w liście do francuskiego rządu bardzo starał się na nią nie powoływać ${ }^{66}$.

Stany Zjednoczone zrewidowały swoje stanowisko w sprawie nieinterwencji, ale pomimo próśb Napoleona III nie zamierzały angażować się w Europie ${ }^{67}$. Uznały bowiem, że bez ważnej potrzeby nie odstąpią od swej tradycyjnej poli-

61 J.M. Belohlavek i in., Manifest destiny and empire. American antebellum expansionism, College Station, TX 1997.

62 H.W. Temple, William H. Seward, [w:] The American Secretaries of State and their diplomacy, ed. S.F. Bemis, vol. 7, New York 1963, s. 30-31.

63 Tamże, s. 107.

64 Nie brakowało wówczas zwolenników interwencji militarnej. M. Cunningham, Mexico and the foreign policy of Napoleon III, Houndmills, Basingstoke, Hampshire-New York 2001, s. 197; H.W. Temple, William H. Seward..., s. 109.

65 J. Sexton, The Monroe Doctrine..., s. 151.

66 M. Cunningham, Mexico..., s. 197; D. Perkins, The Monroe Doctrine, 1867-1907, Baltimore 1937, s. 107-147; W. Seward, The situation and the duty, Auburn, October 31, 1868, [w:] The works of William H. Seward, vol. 5, Boston 1884, s. 540-558; J. Sexton, The Monroe Doctrine..., s. 152.

67 Chodzi o francuskie próby interweniowania po stronie polskich powstańców w $1863 \mathrm{r}$. W. Seward, No. 342, To Mr. Dayton, Department of State, Washington, May 11, 1863, [w:] Message of the president of the United States, and accompanying documents, to the two houses of Congress, at the commencement of the first session of the thirty-eighth congress, vol. 2, Washington 1864, s. 737-739. 
tyki, utożsamianej przez Sewarda ze wskazówkami Washingtona. Duch orędzia z $1823 \mathrm{r}$. był jednak coraz bardziej wyczuwalny. Trudno to dostrzec, patrząc jedynie na stosunek USA do Europy, bo między Washingtonem i Monroe'em nie było tu rozbieżności. Różnił ich pogląd na Zachodnią Hemisferę.

W oficjalnej retoryce USA doktryna Monroe'a pojawiła się dopiero pod koniec XIX w., gdy prezydent Grover Cleveland wystąpił przeciwko brytyjskim roszczeniom terytorialnym wobec Wenezueli ${ }^{68}$. Zasadność amerykańskiej interwencji budziła jednak w tym przypadku wątpliwości, ponieważ Londyn nie dążył do pozyskania nowych terytoriów, ale rozstrzygnięcia wieloletniego sporu. Wielka Brytania mogła się więc czuć zaskoczona. Premier Robert Salisbury w ogóle nie widział przy tym zasadności powoływania się na doktrynę, która nie jest częścią prawa międzynarodowego, nawiązując tym samym do wcześniejszej opinii Disraelego ${ }^{69}$. Mimo to spór udało się rozstrzygnąć polubownie: Albion nie uznał co prawda amerykańskiej doktryny, ale sprawę roszczeń ustalił z USA z pominięciem Wenezueli, uzyskując zresztą zdecydowaną większość terenów, do których rościł sobie prawo ${ }^{70}$. Stany Zjednoczone porzuciły politykę nieinterwencji, aby wzmocnić swoją pozycję w regionie, jednak pozostały wierne duchowi doktryny Monroe'a, rozszerzając strefę bezpieczeństwa $\mathrm{z}$ obszaru swojego państwa na cały kontynent ${ }^{71}$.

68 R. Olney, To Mr. Bayard, Department of State, Washington, July 20, 1895, [w:] Papers relating to the foreign relations of the United States, 1895, part 1, Washington 1896, s. 545-562.

69 R. Salisbury [Gascoyne-Cecil], No. 189, To Sir Julian Pauncefote, Foreign Office, November 26, 1895, [w:] Papers relating to the foreign relations of the United States, $1895 \ldots$, s. $563-567$.

70 Wenezuela do dzisiaj zgłasza pretensje do części terytorium Gujany Brytyjskiej. W. Neuman, In Guyana, a land dispute with Venezuela escalates over oil, „The New York Times” [online], 18.01.2015 [dostęp: 1.02.2017], dostępny w internecie: <https://www.nytimes. com/2015/11/19/world/americas/in-guyana-a-land-dispute-with-venezuela-escalates-overoil.html>. O pierwszym kryzysie wenezuelskim zob. J.J. Mathews, Informal diplomacy in the Venezuelan Crisis of 1896, „The Mississippi Valley Historical Review” 1963, vol. 50, No. 2, s. 195. O problemie Wenezueli w stosunkach brytyjsko-amerykańskich zob.: P.P. Damski, ,, Najbliższe narody”. Stosunki brytyjsko-amerykańskie w dobie prezydentury Theodore'a Roosevelta (1901-1909), Warszawa 2014, rozdz. 1-2; tenże, Wielka Brytania i przyczyny kryzysu wenezuelskiego (1902-1903), „Klio” 2016, t. 36, nr 1, s. 91-110.

71 O zmianie w pojmowaniu polityki zagranicznej przez amerykańską elitę polityczną mogą świadczyć wypowiedzi sekretarza stanu Richarda Olneya. Wskazywał on na znaczenie Nowego Świata dla bezpieczeństwa USA, które odgrywały w nim szczególną rolę. Inni politycy mówili o konieczności światowej ekspansji handlowej Stanów Zjednoczonych w celu zapewnienia im prosperity. W obu przypadkach głównym rywalem jawiła się Wielka Brytania, zwłaszcza w Zachodniej Hemisferze. R. Olney, To Mr. Bayard..., s. 557-558; L. Pastusiak, Kontynuacja i zmiana. Polityka zagraniczna prezydentów Stanów Zjednoczonych od Waszyngtona do Obamy, Warszawa 2016, s. 135-137. 
Do dużo bardziej zdecydowanej akcji USA doszło w 1898 r., gdy wsparły one powstańców kubańskich przeciw ich europejskiej metropolii. Znów jednak działania Amerykanów wykraczały poza doktrynę Monroe'a, w której zaznaczono, że za nieprzyjazne wobec Stanów Zjednoczonych uznane będzie działanie wymierzone w państwo, które „ogłosiło i utrzymało” niepodległośćc ${ }^{2}$. O utrzymaniu kubańskiej suwerenności nie mogło być wówczas mowy. Rząd amerykański znacząco rozszerzył więc zakres stosowania doktryny, co oficjalnie potwierdzone zostało w 1904 r., gdy prezydent Theodore Roosevelt ogłosił jej uzupełnienie, przyznając USA prawo do „zastosowania międzynarodowej siły policyjnej” w przypadku „chronicznego niewłaściwego postępowania lub niemocy [państw latynoamerykańskich i ich rządów - P.P.D.] skutkującej ogólnym rozluźnieniem więzi cywilizowanego społeczeństwa"73. Dawało to szerokie pole do interpretacji i skutkowało tzw. dyplomacją dolarową prezydentów Williama H. Tafta i Woodrowa Wilsona ${ }^{74}$.

Roosevelt nie ograniczał się jednak wyłącznie do Zachodniej Hemisfery. O polityce zagranicznej swego państwa myślał w wymiarze globalnym, co znalazło odzwierciedlenie w jego dużej aktywności międzynarodowej ${ }^{75}$. Włączając się w zażegnanie kryzysu marokańskiego (1905-1906), jako pierwszy amerykański prezydent porzucił zasadę nieinterwencji w sprawach europejskich ${ }^{76}$,

72 J. Monroe, Monroe Doctrine...

73 T. Roosevelt, Message, 6 December, 1904, [w:] Papers relating to the foreign relations of the United States, 1904, Washington, DC 1905, s. XLI.

74 Termin dyplomacja dolarowa jest na ogół wiązany z nazwiskiem Tafta, ale w kadencji Wilsona przeprowadzono znacznie więcej interwencji w Ameryce Łacińskiej niż za czasów jego poprzednika. Autorowi wydaje się zatem zasadne stosowanie tego pojęcia wobec polityki obu prezydentów. L. Pastusiak, Kontynuacja..., s. 180-181; E.S. Rosenberg, Financial missionaries to the world. The politics and culture of dollar diplomacy, 1900-1930, Cambridge, Mass 1999; C. Veeser, A world safe for capitalism. Dollar diplomacy and America's rise to global power, New York 2002; R. Kłosowicz, U.S. Marines jako narzędzie polityki zagranicznej Stanów Zjednoczonych Ameryki, Kraków 2008, s. $92-112$.

75 Szerzej zob.: P.P. Damski, Stanowisko Theodore'a Roosevelta wobec „traktatów Haya-Pauncefote'a” z 5 II 1900 r. i 18 XI 1901 r., „Acta Universitatis Lodziensis. Folia Historica” 2011, t. 86, s. 73-92; tenże, Stosunki brytyjsko-amerykańskie w dobie prezydentury Theodore'a Roosevelta (1901-1909), „Dzieje Najnowsze” 2013, nr 4, s. 79-92; tenże, „Najbliższe narody”...; tenże, Wielka Brytania...; tenże, Rola Stanów Zjednoczonych w zwołaniu i przygotowaniu II Konferencji Pokojowej w Hadze (1907 r.), „Zeszyty Naukowe Uczelni Vistula" 2016, t. 48, nr 3, s. 42-51.

76 Tenże, American non-intervention policy in 'European matters' and the US involvement in the Morocco Crisis of 1905-06, wystapienie na British International History Group Conference w Edynburgu w 2016 r., komputeropis w zbiorach autora. Zob. także: D. Eden, America's first intervention in European politics. Theodore Roosevelt and the European Crisis of 1905-1906, [w:] A companion to Theodore Roosevelt..., s. 350-368. 
na co zwrócił uwagę francuski dyplomata Maurice Paléologue ${ }^{77}$. Maroko to co prawda państwo w Afryce Północnej, ale status tej części świata jest szczególny ze względu na położenie w basenie Morza Śródziemnego, tj. europejskiego mare nostrum $^{78}$. Rząd amerykański był świadomy, że ingeruje w sprawy europejskie, dlatego starał się akcentować przede wszystkim obronę swych interesów handlowych, choć w rzeczywistości były one znikome ${ }^{79}$. Roosevelt uważał, że potencjalny konflikt w Europie oznaczałby „zgubę dla cywilizacji”" ${ }^{80}$. Choć nie upatrywał w kryzysie marokańskim bezpośredniego zagrożenia dla pozycji

77 M. Paleologue, Three critical years 1904-05-06, New York 1957, s. 254.

78 Na przestrzeni dziejów możliwości kontrolowania Afryki Północnej przez Europejczyków zmieniały się, niemniej ich kontakty $\mathrm{z}$ tym regionem zawsze były żywe i traktowane jako sprawa europejska. Morze Śródziemne zaczęto postrzegać jako mare nostrum w okresie Imperium Rzymskiego. W XIX w. mocarstwa europejskie nie zmieniły swojej percepcji, co dobrze widać na przykładzie zjednoczonych Włoch, używających tego terminu w oficjalnej retoryce imperialnej. Również dla Francuzów i Brytyjczyków oczywiste było, że nikt spoza Europy nie ma prawa decydować o sytuacji politycznej w Afryce, a także w części spraw handlowych. Wyjątek czyniono dla Imperium Osmańskiego, a to ze względu na jego pozycję w regionie. Dobrze widać to na przykładzie listy sygnatariuszy traktatu konstantynopolitańskiego z 1888 r. Postrzeganie Afryki Północnej jako obszaru zintegrowanego z Europą (Eurafryka) przetrwało do dziś i ma to konkretne implikacje. Tym samym nie zanikło traktowanie Morza Śródziemnego w kategoriach mare nostrum, co zresztą widać w oficjalnej nazwie włoskiej operacji morsko-powietrznej finansowanej przez Unię Europejską - Operation Mare Nostrum. C.J. Lowe, F. Marzari, Italian foreign policy, 1870-1940, London-New York 2002, s. 34; O.E. Tellegen-Couperus, A short history of Roman law, London-New York 1993, s. 32; Mare Nostrum operation - Marina Militare, „Marina Militare” [online], dostępny w internecie [dostęp: 1.02.2017]: <http:// www.marina.difesa.it/EN/operations/Pagine/MareNostrum.aspx>; P. Hansen, S. Jonsson, Eurafrica. The untold history of European integration and colonialism, London 2015. $\mathrm{Na}$ potoczne rozumienie Morza Śródziemnego jako swego rodzaju jeziora zwracała uwagę jedna z włoskich studentek rozmawiających z Ryszardem Kapuścińskim. J. Mikołajewski, Ryszard Kapuściński - genialny przyjaciel. Wielki reporter zmart 10 lat temu, „Gazeta Wyborcza. Duży Format” [online], 23.01.2017 [dostęp: 1.02.2017], dostępny w internecie: <http://wyborcza.pl/duzyformat/7,127290,21271143,ryszard-kapuscinski-genialny-przyjaciel-wielki-reporter.html>.

79 Zob. dyskusję w Kongresie: February 5, 1906, [w:] Congressional record, containing proceedings and debates of the Fifty-Ninth Congress, first session also special session of the Senate, vol. 40, Washington 1906, s. 2055; January 8, 1906, [w:] Congressional record..., s. 792; January 9, 1906, [w:] Congressional record..., s. 851; January 10, 1906, [w:] Congressional record..., s. 909; January 11, 1906, [w:] Congressional record..., s. 946-947; January 15, 1906, [w:] Congressional record..., s. 1069-1083; January 23, 1906, [w:] Congressional record..., s. 1421; January 24, 1906, [w:] Congressional record..., s. 1469-1480; January 25, 1906, [w:] Congressional record..., s. 1529-1532; January 30, 1906, [w:] Congressional record..., s. 1755.

80 T. Roosevelt, To Whitelaw Reid, absolutely private and confidential, Washington, April 28, 1906, [w:] The letters of Theodore Roosevelt, vol. 5: The big stick, 1905-1907, ed. E.E. Morison, Cambridge, MA 1952, s. 236. 
USA, to był gotów zaangażować się w jego rozwiązanie ${ }^{81}$. Podporządkował więc interesy gospodarcze USA w tym regionie swej wizji geopolitycznej, w myśl której wybuch ogólnoeuropejskiego konfliktu w dłuższej perspektywie musiałby się odbić na amerykańskim bezpieczeństwie ${ }^{82}$.

Następcy Roosevelta nie podzielali jego entuzjazmu dla aktywności globalnej. Polityka zagraniczna Williama H. Tafta kojarzona jest głównie z dyplomacją dolarową oraz zaangażowaniem w Azji. Kontynuował ją utożsamiany $\mathrm{z}$ idealizmem Woodrow Wilson ${ }^{83}$. Obaj nie ingerowali w sprawy europejskie i dopiero gdy w 1914 r. wybuchła wojna, Wilson podjął się prób mediacji, odchodząc tym samym od polityki nieinterwencji. Globalny konflikt zniszczył dotychczasowy system międzynarodowy, a wiele funkcjonujących dotąd norm uległo zawieszeniu. Stany Zjednoczone starały się znaleźć sobie w tych realiach takie miejsce, by zachować jak najwięcej przywilejów, np. swobodę żeglugi i wolność handlu z walczącymi stronami ${ }^{84}$.

Manewr Wilsona wydawał się usprawiedliwiony, gdyż poza pobudkami etycznymi motywowała go chęć ochrony amerykańskich interesów. Prezydent musiał się liczyć z krajową opinią publiczną, która postrzegała konflikt jako sprawę europejską - chciała ochrony przed agresją niemiecką, ale nie zamierzała iść na wojnę $e^{85}$. Niewiele zmieniło w tej kwestii zatopienie Lusitanii. Pomimo narodowego oburzenia oraz krytycznych wypowiedzi części członków amerykańskiego rządu utrzymano neutralność, co de facto oznaczało

81 H.M. Durand, No. 35 Secret and confidential, to the Marquess of Lansdowne, Washington, April 26, 1905, R. 11 p.m., [w:] British documents on the origins of the war, vol. 3: The testing of the Entente, 1904-6, ed. G.P. Gooch, H.W.V. Temperley, London 1928, s. 35; T. Roosevelt, To Cecil Arthur Spring Rice, Washington, May 13, 1905, [w:] The letters of Theodore Roosevelt, vol. 4: The square deal, 1900-1905, ed. E.E. Morison, Cambridge, MA 1951, s. 1177-1778; T. Roosevelt, To William Howard Taft, confidential Glenwood Springs Colorado, April 20, 1905, [w:] The letters of Theodore Roosevelt..., vol. 4, s. 1162-1165.

82 P.P. Damski, „,Najbliższe narody”..., rozdz. 5; D.G. Haglund, That other transatlantic "great rapprochement". France, the United States, and Theodore Roosevelt, [w:] America's transatlantic turn. Theodore Roosevelt and the "discovery" of Europe, ed. H. Krabbendam, J.M. Thompson, New York-Houndmills 2012, s. 131; H. Kissinger, Dyplomacja, Warszawa 2003, s. 43.

83 Wilson twierdził wręcz, że byłoby ,ironią losu, gdyby [jego - P.P.D.] administracja miała się zajmować głównie sprawami zagranicznymi”. Cyt. za: J.M. Cooper, Woodrow Wilson. A biography, New York 2009, rozdz. 9.

84 M.R. Floyd, Abandoning American neutrality. Woodrow Wilson and the beginning of the Great War, August 1914-December 1915, Basingstoke 2013; C.E. Neu, Colonel House. A biography of Woodrow Wilson's silent partner, New York, NY 2015, s. 139-294.

85 M. R. Floyd, Abandoning American neutrality..., s. 127. 
izolację ${ }^{86}$. Do jej porzucenia nie sprowokowała Amerykanów nawet ożywiona działalność agenturalna Niemiec na terenie USA. Nastąpiło to dopiero w obliczu bezpośredniego zagrożenia. Tak zwany telegram Zimmermanna kreował wizję niemiecko-japońsko-meksykańskiego sojuszu przeciw Ameryce i choć była ona nierealna, to uświadomiła decydentom w Waszyngtonie, że nie uciekną od globalnego konfliktu ${ }^{87}$. Prezydent uznał, że Stany Zjednoczone doznały „ran, które nie mogą być tolerowane”, a Amerykanie muszą przestać być „,prowincjuszami” i stać się „obywatelami świata" ${ }^{\circ 8}$. Akt porzucenia izolacji i nieinterwencji wiązał się nie tylko z wzięciem udziału w wojnie europejskiej, ale także z interwencją w Rosji, a następnie współtworzeniem nowego, w założeniu lepszego, wzbogaconego o amerykańskie wartości powojennego ładu międzynarodowego, który zapewniałby USA pokój i bezpieczeństwo ${ }^{89}$. Prezydent Wilson nie przekonał jednak Senatu, który odrzucił traktat wersalski i pakt Ligi Narodów, argumentując taką decyzję obawą o bezpieczeństwo kraju ${ }^{90}$.

Stany Zjednoczone pozostały zatem poza systemem międzynarodowym i przyczyniły się do jego osłabienia. Powróciły do izolacji, choć utrudniały ją silniejsze niż dotychczas zależności ekonomiczne i polityczne ${ }^{91}$. Gdy

86 Neutralność była przyjazna wobec państw ententy, ale fakt, że brytyjska Lusitania przewoziła z USA kontrabandę, w tym broń i amunicję, był dla Waszyngtonu kłopotliwą okolicznością. R. Lansing, The counselor of the Department of State to the Secretary of State, [Washington], May 9, 1915, [w:] Papers relating to the foreign relations of the United States. The lansing papers, 1914-1920, vol. 1, Washington 1939, s. 387-388; A.J. Peters, The assistant of the treasury to the counselor for the Department of State, Washington, May 8, 1915, [w:] Papers relating to the foreign relations of the United States: The lansing papers..., s. 385-386; T.W. Wilson, To the Secretary of State, Washington, 10 May, 1915, [w:] Papers relating to the foreign relations of the United States. The lansing papers..., s. 387.

87 T. Boghardt, The Zimmermann telegram. Intelligence, diplomacy, and America's entry into World War I, Annapolis, Maryland 2012; B. W. Tuchman, Telegram Zimmermanna, Warszawa 1989.

88 T.W. Wilson, Second inaugural address, „The Avalon Project” [online], 5.03 .1917 [dostęp: 5.01.2018], dostępny w internecie: <http://avalon.law.yale.edu/20th_century/wilson2.asp>.

89 M. MacMillan, Peacemakers. The Paris Peace Conference of 1919 and its attempt to end war, London 2003. Ostatnio książka ta ukazała się również po polsku: M. MacMillan, Paryż 1919. Sześć miesięcy, które zmienity świat. Konferencja pokojowa w Paryżu w 1919 roku i próba zakończenia wojny, Oświęcim 2018.

90 Główny przeciwnik Ligi Narodów, senator Henry Cabot Lodge, obawiał się, że będzie ona używać siły przeciw każdemu, kto nie podporządkuje się jej zaleceniom. D. Mervin, Henry Cabot Lodge and the League of Nations, „Journal of American Studies” 1971, vol. 4, No. 2, s. 201-214.

91 Chodzi oczywiście o reparacje oraz fakt, że w latach dwudziestych XX w. USA pozostawały najważniejszym kredytodawcą Europy. Izolacja polityczna była też jednak ograniczona, przynajmniej początkowo. Gdy Francja wystąpiła z propozycją traktatu 
w Europie wybuchła kolejna wojna, USA znów pozostawały na uboczu, choć wcześniej taka polityka poniosła już fiasko.

Przełom nastąpił po drugiej wojnie światowej. USA były jednym z architektów nowego ładu międzynarodowego, ale i jego filarem. Obecność wojsk amerykańskich w Europie stała w kontrze do dotychczasowej polityki nieinterwencji i izolacjonizmu. Nie jest to jednak pełen obraz sytuacji. Trzeba bowiem zaznaczyć, że komunizm i polityka sowiecka, utożsamiana $\mathrm{z}$ rosyjskim nacjonalizmem, uznane zostały za zagrożenie dla Europy i Ameryki ${ }^{92}$. Porzucenie nieinterwencji i izolacji oraz przejście do doktryny powstrzymywania było uzasadnione i zgodne $\mathrm{z}$ nadrzędnym celem polityki zagranicznej USA, czyli zapewnieniem bezpieczeństwa państwa. Tam gdzie amerykańskie interesy nie były zagrożone, USA okazywały désintéressement, m.in. w ramach ONZ. Sekretarz stanu Dean Acheson, kreśląc zakres zainteresowania polityki Stanów Zjednoczonych, wskazywał na Europę Zachodnią i wyspiarską Azję ${ }^{93}$. Jego założenia zweryfikowała jednak zaskakująca napaść Korei Północnej na Południową ${ }^{94}$. Milczenie Moskwy przekonało Amerykanów, że odpowiedzialność za to wydarzenie spoczywa na $\mathrm{ZSRR}^{95}$, i skłoniło decydentów w Waszyngtonie do korekty przyjętych założeń oraz uznania, że zagrożeniem dla USA jest także rozprzestrzenianie się komunizmu w Azji. Przyjęte wówczas wektory polityki zagranicznej Stanów Zjednoczonych utrzymywane były przez cały okres zimnej wojny, choć aż do prezydentury Ronalda Reagana Ameryka nie wykorzystywała całego swojego potencjału ${ }^{96}$.

zakazującego prowadzenia wojen między oboma państwami, Waszyngton nie mógł całkowicie zignorować tej inicjatywy i doprowadził do przekształcenia go jedynie w powszechny pakt o wyrzeczeniu się wojny.

92 J.L. Gaddis, Strategie powstrzymywania. Analiza polityki bezpieczeństwa narodowego Stanów Zjednoczonych w okresie zimnej wojny, Warszawa 2007; G.F. Kennan, [No.] 8963, To James Byrnes, Moscow [Long Telegram], Received 3:52 P. M., „Wilson Center” [online], 22.02.1946 [dostęp: 16.02.2018], dostępny w internecie: $<$ http://digitalarchive. wilsoncenter.org/document/116178>.

93 R.L. Beisner, Dean Acheson. A life in the Cold War, Oxford-New York 2006, s. 327-328.

94 H. Kissinger, Dyplomacja..., s. 516-518; tenże, O Chinach, Wołowiec 2014, s. 140.

95 A.G. Kirk, 795.00/6-2550: Telegram, Top Secret, The Ambassador in the Soviet Union to the Secretary of State, Moscow, June 25, 1950-3 p.m. [Received June 25-9:59 a.m.], [w:] Foreign relations of the United States, 1950, Korea, ed. J.P. Glennon, vol. 7, Washington 1976, s. 139-140; tenże, 330/6-2550: Telegram, Confidential, The Ambassador in the Soviet Union to the Secretary of State, Moscow, June 25, 1950-5 p.m. [Received June 25-11:39 a.m.], [w:] Foreign relations of the United States, 1950..., s. 141.

96 R. Rosencrance, Z. Steiner, History... 


\section{Wnioski: dziedzictwo polityki nieinterwencji}

Izolacjonizm i nieinterwencja (zwłaszcza $\mathrm{w}$ sprawach europejskich) mają w amerykańskiej mentalności i praktyce dyplomatycznej długą tradycję. Nie wynikają bezpośrednio z doktryny Monroe'a, lecz z politycznej i intelektualnej spuścizny George'a Washingtona; orędzie z 1823 r. było jedynie jej modyfikacją. Stany Zjednoczone zmieniały swoją politykę pod wpływem impulsów, emocji i przeświadczenia o zagrożeniu dla swego bezpieczeństwa. Przez pryzmat tego ostatniego w Ameryce postrzegano także problem ładu międzynarodowego. Izolacjonizm i nieinterwencję motywowano również niechęcią do Europy, którą USA potrafiły przełamać wyłącznie w obliczu wspólnego zagrożenia, co można było zaobserwować w obu wojnach światowych i zimnej wojnie. Gdy tylko niebezpieczeństwo znikało, a wraz z nim wspólne doświadczenie, nad Potomakiem wzrastały sceptycyzm do relatywnie młodej polityki sojuszy oraz chęć powrotu do tego co tradycyjne. Jak podkreśla Timothy Garton Ash, widać to było zaraz po konferencji paryskiej z 1919 r., a w ostatnim czasie - po drugiej wojnie w Zatoce Perskiej ${ }^{97}$.

Zmniejszenie amerykańskiego zaangażowania w Europie przyspieszyło w okresie prezydentury Baracka Obamy i powiązane było z tzw. resetem w stosunkach z Rosją oraz zwrotem w stronę Pacyfiku ${ }^{98}$. Nie oznaczało to jednak skłócania się z europejskimi partnerami czy definitywnego odcinania się od Starego Kontynentu. Administracja Trumpa zdecydowała się natomiast na działania radykalne. Prezydent podąża drogą tradycyjnego unikania zaangażowania w sprawy europejskie, ale używa przy tym retoryki nacjonalistycznej i antyeuropejskiej, dobrze zakorzenionej w amerykańskiej narracji politycznej i praktyce dyplomatycznej ${ }^{99}$. Podobnie jak w przeszłości zmiana amerykańskiego stanowiska wobec Europy motywowana jest dziś zagrożeniem bezpieczeństwa narodowego USA. Oznacza to, że Donald Trump i jego

97 T. Garton Ash, Anti-Europeanism in America, „Hoover Digest Research \& Opinion on Public Policy" 2003, No. 2, dostępny w internecie [dostęp: 12.04.2018]: <http://www. hoover.org/research/anti-europeanism-america>.

98 R.S. Ross, The problem with the pivot, „Foreign Affairs” [online], 1.11.2012 [dostęp: 1.06.2018], dostępny w internecie: <https://www.foreignaffairs.com/articles/asia/201211-01/problem-pivot>; P. Swieboda, Who's afraid of the big bad pivot?, „Foreign Affairs" [online], 20.04.2012 [dostęp: 1.06.2018], dostępny w internecie: <https://www. foreignaffairs.com/articles/poland/2012-12-04/who-s-afraid-big-bad-pivot>.

99 Poczucie wyższości wobec Starego Kontynentu nie zniknęło nawet w okresie bliskiej współpracy w czasie zimnej wojny. Henry Kissinger zauważał wówczas ironicznie, że nie wie, do kogo ma zadzwonić, gdy chce rozmawiać z Europą. 
otoczenie definiują swoich sojuszników z NATO jako potencjalnych rywali i stawiają interesy Stanów Zjednoczonych - tak jak je rozumieją - w opozycji do politycznych i gospodarczych celów tych państw.

Niezależnie od tego, czy obawy Białego Domu są słuszne, jego retoryka zawiera - podobnie jak w przeszłości - duży ładunek emocjonalny, przeznaczony na użytek wewnętrzny. Ma to usprawiedliwiać kolejne wolty i de facto powrót do izolacji, a tym samym do podziału zjednoczonego dotąd świata Zachodu.

\section{Bibliografia}

Ambrosius L.E., The Great War, Americanism revisited, and the anti-Wilson crusade, [w:] A companion to Theodore Roosevelt, ed. S. Ricard, Chichester, West Sussex-Malden, MA 2011. The American Secretaries of State and their diplomacy, vol. 7, ed. S. F. Bemis, New York 1963. America's transatlantic turn. Theodore Roosevelt and the "discovery" of Europe, ed. H. Krabbendam, J.M. Thompson, New York-Houndmills 2012.

Amerykomania. Ksiegga jubileuszowa profesora dra hab. Andrzeja Mani, t. 1, red. W. Bernacki, A. Walaszek, Kraków 2009.

Balleck B.J., When the ends justify the means. Thomas Jefferson and the Louisiana Purchase, „Presidential Studies Quarterly” 1992, vol. 22, No. 4.

Beisner R.L., Dean Acheson. A life in the Cold War, Oxford-New York 2006.

Belohlavek J.M. i in., Manifest Destiny and empire. American antebellum expansionism, College Station, TX 1997.

Bernstein S., Jefferson and the French Revolution, ,Science \& Society” 1943, vol. 7, No. 2. Boghardt T., The Zimmermann telegram. Intelligence, diplomacy, and America's entry into World War I, Annapolis, Maryland 2012.

Brands H.W., Andrew Jackson. His life and times, New York 2006.

British documents on the origins of the war, vol. 3: The testing of the Entente, 1904-6, ed. G.P. Gooch, H.W.V. Temperley, London 1928.

Buel R., America on the brink. How the political struggle over the war of 1812 almost destroyed the young republic, New York, NY 2005.

Calamur K., Why Europe is worried about Donald Trump's latest remarks, „The Atlantic” [online], 16.01.2017 [dostęp: 1.02.2017], dostępny w internecie: <https://www.theatlantic. com/news/archive/2017/01/europe-trump/513248/>.

Cameron R.E., Neal L., Historia gospodarcza świata. Od paleolitu do czasów najnowszych, Warszawa 2010.

A companion to Theodore Roosevelt, ed. S. Ricard, Chichester, West Sussex-Malden, MA 2011. Congressional record, containing proceedings and debates of the Fifty-Ninth Congress, first session also special session of the Senate, vol. 40, Washington 1906.

Cooper J.M., Woodrow Wilson. A biography, New York 2009.

Crapol E.P., John Quincy Adams and the Monroe Doctrine. Some new evidence, „Pacific Historical Review" 1979, vol. 48, No. 3.

Cunningham M., Mexico and the foreign policy of Napoleon III, Houndmills, Basingstoke, Hampshire-New York 2001. 
Damski P.P., American non-intervention policy in 'European matters' and the US involvement in the Morocco Crisis of 1905-06, 2016, komputeropis w zbiorach autora.

Damski P.P., „Najbliższe narody”. Stosunki brytyjsko-amerykańskie $w$ dobie prezydentury Theodore'a Roosevelta (1901-1909), Warszawa 2014.

Damski P.P., Rola Stanów Zjednoczonych w zwotaniu i przygotowaniu II Konferencji Pokojowej w Hadze (1907 r.), „Zeszyty Naukowe Uczelni Vistula” 2016, t. 48, nr 3.

Damski P.P., Stanowisko Theodore'a Roosevelta wobec , traktatów Haya-Pauncefote'a” z 5 II 1900 r. i 18 XI 1901 r., „Acta Universitatis Lodziensis. Folia Historica” 2011, t. 86.

Damski P.P., Stosunki brytyjsko-amerykańskie $w$ dobie prezydentury Theodore'a Roosevelta (1901-1909), „Dzieje Najnowsze” 2013, nr 4.

Damski P.P., Wielka Brytania i przyczyny kryzysu wenezuelskiego (1902-1903), „Klio” 2016, t. $36, \mathrm{nr} 1$.

Daszyńska J., Misje Benjamina Franklina w Londynie w latach 1757-1775, Łódź 1994.

The Declaration of independence, 4.07.1776 [dostęp: 16.05.2018], dostępny w internecie: $<\mathrm{http}$ //www.ushistory.org/declaration/document/>.

Deikmann K., Gove M., Full transcript of interview with Donald Trump, „The Times” [online], 16.01.2017 [dostęp: 1.02.2017], dostępny w internecie: <http://www.thetimes.co.uk/ article/full-transcript-of-interview-with-donald-trump-5d39sr09d $>$.

Disraeli B., Our relations with the United States, June 16, 1856, [w:] Hansard parliamentary debates. House of commons, vol. 142, London 1856.

Donald Trump's speech could have been written by Poland's populists, „The Economist” [online], 7.07.2017 [dostęp: 14.08.2017], dostępny w internecie: <https://www.economist. $\mathrm{com} /$ news/europe/21724892-warsaw-americas-president-barely-mentions-democracydonald-trumps-speech-could-have-been>.

Eden D., America's first intervention in European politics. Theodore Roosevelt and the European Crisis of 1905-1906, [w:] A companion to Theodore Roosevelt, ed. S. Ricard, Chichester, West Sussex-Malden, MA 2011.

Emotions in politics. The affect dimension in political tension, ed. N. Demertzis, Basingstoke 2013.

Europa i świat w epoce restauracji, romantyzmu i rewolucji, 1815-1849, t. 2, red. W. Zajewski, Warszawa 1991.

EU's Donald Tusk takes aim at Donald Trump over Iran, trade tariffs, „Deutsche Welle” [online], 16.05.2018 [dostęp: 1.06.2018], dostępny w internecie: <http://www.dw.com/en/ eus-donald-tusk-takes-aim-at-donald-trump-over-iran-trade-tariffs/a-43813124>.

Floyd M.R., Abandoning American neutrality. Woodrow Wilson and the beginning of the Great War, August 1914-December 1915, Basingstoke 2013.

Foreign relations of the United States, 1950, Korea, vol. 7, ed. J.P. Glennon, Washington 1976.

Frum D., Trump's trip was a catastrophe for U.S.-Europe Relations, „The Atlantic” [online], 28.05.2017 [dostęp: 14.08.2017], dostępny w internecie: $<$ https://www.theatlantic.com/ international/archive/2017/05/trump-nato-germany/528429/>.

Gaddis J.L., Strategie powstrzymywania. Analiza polityki bezpieczeństwa narodowego Stanów Zjednoczonych w okresie zimnej wojny, Warszawa 2007.

Gaddis J.L., Surprise, security, and the American experience, Cambridge, MA 2004.

Garton Ash T., Anti-Europeanism in America, „Hoover Digest. Research \& Opinion on Public Policy” 2003, No. 2, dostępny w internecie [dostęp: 12.04.2018]: <http://www.hoover.org/ research/anti-europeanism-america>. 
Gilderhus M.T., The Monroe Doctrine. Meanings and implications, „Presidential Studies Quarterly" 2006, vol. 36, No. 1.

Gillespie P., Trump: Tearing up NAFTA „, will be fine”, „CNN Money” [online], 11.10.2017 [dostęp: 1.06.2018], dostępny w internecie: <http://money.cnn.com/2017/10/11/news/ economy/trump-nafta/index.html>.

Grierson J., Davies C., Wintour P., Trump says west is at risk, during nationalistic speech in Poland, „The Guardian” [online], 6.07.2017 [dostęp: 14.08.2017], dostępny w internecie: $<$ http://www.theguardian.com/us-news/2017/jul/06/donald-trump-warn-future-west-in-doubt-warsaw-speech>.

Haglund D.G., That other transatlantic "great rapprochement". France, the United States, and Theodore Roosevelt, [w:] America's transatlantic turn. Theodore Roosevelt and the "discovery" of Europe, ed. H. Krabbendam, J. M. Thompson, New York-Houndmills 2012.

Hansard parliamentary debates. House of commons, vol. 142, London 1856.

Hansen P., Jonsson S., Eurafrica. The untold history of European integration and colonialism, London 2015.

Harper J.L., American Machiavelli. Alexander Hamilton and the origins of U.S. foreign policy, Cambridge, UK-New York 2004.

Harris G., Mike Pompeo, wasting no time, warns Europe about Iran deal, „The New York Times" [online], 28.04.2018 [dostęp: 1.06.2018], dostępny w internecie: <https://www. nytimes.com/2018/04/27/world/europe/mike-pompeo-nato-russia-iran.html>.

Henley J., Donald Trump’s Europe tour leaves leaders strangely shaken, „The Guardian” [online], 27.05.2017 [dostęp: 14.08.2017], dostępny w internecie: <http://www.theguardian. com/us-news/2017/may/27/donald-trumps-europe-tour-leaves-leaders-shaken>.

Herring G.C., From colony to superpower. U.S. foreign relations since 1776, New York 2008. History and neorealism, ed. E. R. May, R. Rosencrance, Z. Steiner, Cambridge-New York 2010. Hobsbawm E.J., The age of revolution. Europe 1789-1848, London 1988.

Hope K., Davos 2017: Trump, China and Brexit set to dominate, „BBC News” [online], 16.01.2017 [dostęp: 21.06.2018], dostępny w internecie: <http://www.bbc.com/news/ business-38585505>.

Hughes J.M., Emotion and high politics. Personal relations at the summit in late nineteenth-century Britain and Germany, Berkeley 1983.

Humphreys R. A., Presidential address. Anglo-American rivalries and the Venezuela Crisis of 1895, „Transactions of the Royal Historical Society Fifth Series” 1967, vol. 17.

Johnston A.M., Sex and Gender in Roosevelt's America, [w:] A companion to Theodore Roosevelt, ed. S. Ricard, Chichester, West Sussex-Malden, MA 2011.

Jones M. A., Historia USA, Gdańsk 2003.

Kagan R., Dangerous nation, New York 2006.

Kennan G.F., [No.] 8963, To James Byrnes, Moscow [Long Telegram], Received 3:52 P.M., „Wilson Center" [online], 22.02.1946 [dostęp: 16.02.2018], dostępny w internecie: $<22.02 .1946$, http://digitalarchive.wilsoncenter.org/document/116178>.

Kennedy P., Mocarstwa świata. Narodziny, rozkwit, upadek. Przemiany gospodarcze i konflikty zbrojne w latach 1500-2000, Warszawa 1984.

King J., Diamond J., Trump team floats a 10\% tariff on imports, „CNN” [online], 21.12.2016 [dostęp: 6.02.2017], dostępny w internecie: <http:/www.cnn.com/2016/12/21/politics/ donald-trump-tariffs/index.html>.

Kissinger H., Dyplomacja, Warszawa 2003. 
Kissinger H., O Chinach, Wołowiec 2014.

Kłosowicz R., U.S. Marines jako narzędzie polityki zagranicznej Stanów Zjednoczonych Ameryki, Kraków 2008.

Lai K.K.R., Parlapiano A., What we know about Donald Trump Jr.'s Russia meeting, „The New York Times" [online], 18.07.2017 [dostęp: 14.08.2017], dostępny w internecie: <https:// www.nytimes.com/interactive/2017/07/18/us/politics/donald-trump-jr-russia-meeting.html>.

Lauren P.G., Diplomats and bureaucrats. The first institutional responses to twentieth-century diplomacy in France and Germany, Stanford, CA 1976.

Lawler D., Donald Trump's proposed tariff on US goods made overseas could extend to all imports, ally says, „The Telegraph” [online], 2.12.2016 [dostęp: 6.02.2017], dostępny w internecie: <http://www.telegraph.co.uk/news/2016/12/04/donald-trumps-proposed-tariff-us-goods-made-overseas-could-extend/>.

The letters of Theodore Roosevelt, vol. 4: The square deal, 1900-1905, ed. E.E. Morison, Cambridge, MA 1951.

The letters of Theodore Roosevelt, vol. 5: The big stick, 1905-1907, ed. E.E. Morison, Cambridge, MA 1952.

Libiszowska Z., Tomasz Jefferson, Wrocław 1984.

Lowe C.J., Marzari F., Italian foreign policy, 1870-1940, London-New York 2002.

Lowrey A., The limits of „,Made in America” economics, „The Atlantic” [online], 20.07.2017 [dostęp: 14.08.2017], dostępny w internecie: <https://www.theatlantic.com/business/ archive/2017/07/made-in-america/534339/>.

Łepkowski T., Ameryka Łacińska. Rewolucje niepodległościowe i początki nowych państwowości, [w:] Europa i świat w epoce restauracji, romantyzmu i rewolucji, 1815-1849, red. W. Zajewski, t. 2, Warszawa 1991.

MacMillan M., Paryż 1919. Sześć miesięcy, które zmienity świat. Konferencja pokojowa w Paryżu w 1919 roku i próba zakończenia wojny, Oświęcim 2018.

MacMillan M., Peacemakers. The Paris Peace Conference of 1919 and its attempt to end war, London 2003.

Mania A., Department of State 1789-1939. Pierwsze 150 lat udzialu w polityce zagranicznej USA, Kraków 2011.

Mare Nostrum operation - Marina Militare, „Marina Militare” [online], dostępny w internecie [dostęp: 1.02.2017]: <http://www.marina.difesa.it/EN/operations/Pagine/MareNostrum.aspx>.

Mathews J.J., Informal diplomacy in the Venezuelan Crisis of 1896, „The Mississippi Valley Historical Review" 1963, vol. 50, No. 2.

Mervin D., Henry Cabot Lodge and the League of Nations, „Journal of American Studies” 1971, vol. 4, No. 2.

Message of the president of the United States, and accompanying documents, to the two houses of Congress, at the commencement of the first session of the thirty-eighth congress, vol. 2, Washington 1864.

Mikołajewski J., Ryszard Kapuściński-genialny przyjaciel. Wielki reporter zmart 10 lat temu, „Gazeta Wyborcza. Duży Format” [online], 23.01.2017 [dostęp: 1.02.2017], dostępny w internecie: <http://wyborcza.pl/duzyformat/7,127290,21271143,ryszard-kapuscinski-genialny-przyjaciel-wielki-reporter.html $>$.

Monroe J., Monroe Doctrine, „,The Avalon Project”, 2.12.1823 [dostęp: 26.09.2016], dostępny w internecie: $<$ Avalon Project, 02.12.1823, http://avalon.law.yale.edu/19th_century/monroe.asp>. 
Moore J.B., The principles of American diplomacy, New York 1918.

Mroziewicz R., Dyplomacja USA wobec Ameryki Centralnej 1822-1850, Wrocław 1986.

Neu C.E., Colonel House. A biography of Woodrow Wilson's silent partner, New York, NY 2015.

Neuman W., In Guyana, a land dispute with Venezuela escalates over oil, „The New York Times" [online], 18.01.2015 [dostęp: 1.02.2017], dostępny w internecie: <https://www. nytimes.com/2015/11/19/world/americas/in-guyana-a-land-dispute-with-venezuela-escalates-over-oil.html>.

Nichols I.C., The Russian ukase and the Monroe Doctrine. A re-evaluation, „Pacific Historical Review" 1967, vol. 36, No. 1.

Nicolson H., The Congress of Vienna. A study in allied unity: 1812-1822, New York 1964.

An odd moment for Davos, „The New York Times” [online], 18.01.2017 [dostęp: 1.02.2017], dostępny w internecie: <https://www.nytimes.com/2017/01/18/opinion/an-odd-momentfor-davos.html>.

Osterhammel J., Historia XIX wieku. Przeobrażenie świata, Poznań 2013.

Otte T.G., The foreign office mind. The making of British foreign policy, 1865-1914, CambridgeNew York 2011.

Owens K. N., Frontiersman for the Tsar. Timofei Tarakanov and the expansion of Russian America, „Montana. The Magazine of Western History” 2006, vol. 56.

Paleologue M., Three critical years 1904-05-06, New York 1957.

The Papers of Thomas Jefferson, vol. 33, Princeton, NJ 2006.

Papers relating to the foreign relations of the United States, 1895, part 1, Washington 1896. Papers relating to the foreign relations of the United States, 1904, Washington, DC 1905.

Papers relating to the foreign relations of the United States. The lansing papers, 1914-1920, vol. 1, Washington 1939.

Pastusiak L., Droga Stanów Zjednoczonych do mocarstwowości. Studia amerykanistyczne, Łódź 2007.

Pastusiak L., Kontynuacja i zmiana. Polityka zagraniczna prezydentów Stanów Zjednoczonych od Waszyngtona do Obamy, Warszawa 2016.

Perkins D., The American approach to foreign policy, Cambridge, MA 1955.

Perkins D., A history of the Monroe Doctrine, Boston 1955.

Perkins D., The Monroe doctrine 1823-1826, Cambridge, Mass 1932.

Perkins D., The Monroe doctrine, 1867-1907, Baltimore 1937.

Phipps C., Trump rages at „dumb deal” with Australia over refugee resettlement - as it happened, „The Guardian” [online], 2.02.2017 [dostęp: 14.08.2017], dostępny w internecie: <http://www.theguardian.com/australia-news/live/2017/feb/02/donald-trump-dumb-deal-australia-refugee-resettlement-live $>$.

Plischke E., U.S. Department of State. A reference history, Westport, Conn 1999.

Rankin J., EU opens WTO case against Trump's steel and aluminium tariffs, „The Guardian” [online], 1.06.2018 [dostęp: 1.06.2018], dostępny w internecie: <https://www.theguardian.com/business/2018/jun/01/eu-starts-retaliation-against-donald-trumps-steel-and-aluminium-tariffs $>$.

Robertson W.S., Metternich's attitude toward revolutions in Latin America, „The Hispanic American Historical Review" 1941, vol. 21, No. 4.

Rosenberg E.S., Financial missionaries to the world. The politics and culture of dollar diplomacy, 1900-1930, Cambridge, Mass 1999. 
Ross A.A.G., Realism, emotion, and dynamic allegiances in global politics, „International Theory" 2013, vol. 5, No. 2.

Ross R.S., The problem with the pivot, „Foreign Affairs” [online], 1.11.2012 [dostęp: 1.06.2018], dostępny w internecie: $<$ https://www.foreignaffairs.com/articles/asia/2012-11-01/problem-pivot>.

Russia. The ,cloud” over the Trump White House, „BBC News” [online], 10.07.2017 [dostęp: 14.08.2017], dostępny w internecie: $<$ http://www.bbc.com/news/world-us-canada-38966846>.

Sasley B., Emotions in international relations, „E-International Relations” [online], 12.06.2013 [dostęp: 5.03.2018], dostępny w internecie: $<$ https://www.e-ir.info/2013/06/12/emotions-in-international-relations/>.

Sasley B., Theorizing States' Emotions, „International Studies Review” 2011, vol. 13, No. 3.

Schellenberg T.R., Jeffersonian origins of the Monroe Doctrine, „The Hispanic American Historical Review" 1934, vol. 14, No. 1.

Schulzinger R.D., The making of the diplomatic mind. The training, outlook, and style of the United States Foreign Service officers, 1908-1931, Middletown, Connecticut 1975.

Sexton J., The Monroe Doctrine. Empire and nation in nineteenth-century America, New York 2011.

Sink J., Wingrove J., Trump warns Trudeau on Nafta: Fair deal or no deal, „Bloomberg” [online], 1.06.2018 [dostęp: 1.06.2018], dostępny w internecie: <https://www.bloomberg. com/news/articles/2018-06-01/trump-warns-trudeau-on-nafta-fair-deal-or-no-deal-at-all>.

Sloane W.M., The world aspects of the Louisiana Purchase, „The American Historical Review” 1904, vol. 9, No. 3.

Steiner Z., Foreign Office and foreign policy, 1898-1914, London 1969.

Swanson A., White House to impose metal tariffs on E.U., Canada and Mexico, „The New York Times" [online], 1.06.2018 [dostęp: 1.06.2018], dostępny w internecie: $<$ https://www.nytimes.com/2018/05/31/us/politics/trump-aluminum-steel-tariffs.html $>$.

Swieboda P., Who's afraid of the big bad pivot?, „Foreign Affairs” [online], 20.04.2012 [dostęp: 1.06.2018], dostępny w internecie: <https://www.foreignaffairs.com/articles/ poland/2012-12-04/who-s-afraid-big-bad-pivot>.

Tellegen-Couperus O.E., A short history of Roman law, London-New York 1993.

Temple H.W., William H. Seward, [w:] The American Secretaries of State and their diploma$c y$, vol. 7, ed. S.F. Bemis, New York 1963.

Thrush G., Davis J.H., Trump, in Poland, asks if west has the 'will to survive', „, The New York Times" [online], 6.07.2017 [dostęp: 14.08.2017], dostępny w internecie: $<$ https://www.nytimes.com/2017/07/06/world/europe/donald-trump-poland-speech.html>.

Tindall G. B., Shi D.E., America. A narrative history, New York 2016.

Tocqueville A. de, O demokracji w Ameryce, Warszawa 2005.

Trump threatens Europe, says Brussels chief, „The Times” [online], 2.01.2017 [dostęp: 1.02.2017], dostępny w internecie: $<$ http://www.thetimes.co.uk/article/trump-threatens-europe-says-brussels-chief-2lwx02k8d $>$.

Tuchman B.W., Telegram Zimmermanna, Warszawa 1989.

Usborne D., If Trump kills off Nafta it will be at his own peril - and the peril of America, „The Independent" [online], 20.10.2017 [dostęp: 1.06.2018], dostępny w internecie: <http:// www.independent.co.uk/voices/donald-trump-populist-kill-off-nafta-mexico-canada-end-of-globalisation-a8011976.html>. 
Veeser C., A world safe for capitalism. Dollar diplomacy and America's rise to global power, New York 2002.

Wallerstein I., The modern world-system III. The second era of great expansion of the capitalist world-economy, 1730-1840s, Berkeley-Los Angeles-London 2011.

Wallerstein I., The modern world-system. Capitalist agriculture and the origins of the European world-economy in the sixteenth century, New York-San Francisco-London 1974.

Washington G., Farewell address, „The Avalon Project” [online], dostępny w internecie [dostęp: 8.04.2016]: <Avalon Project, http://avalon.law.yale.edu/18th_century/washing.asp>.

Wilson T.W., Second inaugural address, „The Avalon Project” [online], 5.03.1917 [dostęp: 5.01.2018], dostępny w internecie: $<$ http://avalon.law.yale.edu/20th_century/wilson2.asp $>$.

Woleński J., Donald Trump wraca do stynnej Doktryny Monroe'a. Polski nie powinno to cieszyć, „Polityka” [online], 23.01.2017 [dostęp: 1.02.2017], dostępny w internecie: <http://www. polityka.pl/tygodnikpolityka/swiat/1691298,1,donald-trump-wraca-do-slynnej-doktrynymonroea-polski-nie-powinno-to-cieszyc.read>.

Woodward C. V., The age of reinterpretation, „The American Historical Review” 1960, vol. 66, No. 1.

Wordliczek Ł., Czy nowy prezydent Stanów Zjednoczonych prowadzi nowa politykę zagraniczna i dlaczego nie?, [w:] Amerykomania. Ksiegga jubileuszowa profesora dra hab. Andrzeja Mani, t. 1, red. W. Bernacki, A. Walaszek, Kraków 2009.

The works of William H. Seward, vol. 5, Boston 1884.

Zakaria F., From wealth to power. The unusual origins of America's world role, Princeton, NJ 1998.

Zurcher A., Three reasons behind Trump ditching Iran deal, „BBC News” [online], 8.05. 2018 [dostęp: 1.06.2018], dostępny w internecie: <https://www.bbc.com/news/world-us-canada-43902372>.

Żakowski J., Trump nie najlepszy dla świata, ale najlepszy dla Ameryki?, „TOK FM” [online], 9.11.2016 [dostęp: 7.01.2017], dostępny w internecie: <http://audycje.tokfm.pl/podcast/ Trump-nie-najlepszy-dla-swiata-ale-najlepszy-dla-Ameryki/43212>.

Żelazińska A., W świecie dyplomacji coraz gorzej z kindersztubą, ,Polityka” [online], 18.07.2017 [dostęp: 15.08.2017], dostępny w internecie: <http://www.polityka.pl/tygodnikpolityka/ludzieistyle/1712540,1,w-swiecie-dyplomacji-coraz-gorzej-z-kindersztuba.read>. 